\title{
Seasonal changes in foraminiferal assemblages along environmental gradients in Adventfjorden (West Spitsbergen)
}

\author{
Małgorzata Kucharska ${ }^{1}$ (1) Agnieszka Kujawa ${ }^{1} \cdot$ Joanna Pawłowska ${ }^{1} \cdot$ Magdalena Łącka ${ }^{1}$. Natalia Szymańska ${ }^{1}$. \\ Ole Jørgen Lønne ${ }^{2} \cdot$ Marek Zajączkowski ${ }^{1}$
}

Received: 14 February 2018 / Revised: 18 December 2018 / Accepted: 19 December 2018 / Published online: 29 December 2018

(c) The Author(s) 2018

\begin{abstract}
Foraminifera are numerically abundant components of the benthic fauna; thus, they are very important compounds in glaciomarine environments. However, ongoing oceanographic changes may influence their distribution, abundances and diversity differently at different times of the year. In the present study, we aimed to assess seasonal environmental changes in an Arctic fjord (Adventfjorden, W Spitsbergen) and the structure and distribution of benthic foraminiferal assemblages during four seasons (January, May, August, November). The study revealed that the benthic foraminiferal assemblages in Adventfjorden are susceptible to environmental changes related to enhanced inflow of shelf-transformed water (STW). We distinguished three zones in the fjord: (1) the deeper outer part influenced by STW, with living specimens staying in the few uppermost layers of sediment, (2) the shallower interior influenced by freshwater outflows and high sediment load, resulting in the dominance of opportunistic glaciomarine taxa constantly buried in the sediment, and (3) the central part, where the seasonal variation in the foraminifera assemblage reflects the interplay between the influence of riverine inputs and STW. Our study also revealed that the presence of STW in Adventfjorden favours an early spring appearance of juvenile foraminifera; however, the majority of the specimens are later withered and do not contribute to the summer pool of mature individuals. On the other hand, the majority of the mature specimens can survive during the winter because of sufficient organic matter stocks and year-long ice-free conditions.
\end{abstract}

Keywords Arctic $\cdot$ Seasonality $\cdot$ Fjord $\cdot$ Svalbard $\cdot$ Vertical migration $\cdot$ Environmental gradient

\section{Introduction}

Arctic fjords encompass several distinctive oceanographic environments, with strong gradients in many key environmental parameters, including salinity, suspension load and sedimentation (Syvitski and Skei 1983). The oceanographic conditions of west Spitsbergen fjords are mainly shaped by the inflow of warm and saline Atlantic Waters (AW)

Electronic supplementary material The online version of this article (https://doi.org/10.1007/s00300-018-02453-5) contains supplementary material, which is available to authorised users.

Małgorzata Kucharska

malkuch@iopan.gda.pl

1 Institute of Oceanology, Polish Academy of Sciences, Powstańców Warszawy 55, 81-712 Sopot, Poland

2 The University Centre in Svalbard (UNIS), P.O. Box 156, 9171 Longyearbyen, Norway transported by the West Spitsbergen Current (Nilsen et al. 2016). The AW mix with Arctic and local waters over the West Spitsbergen shelf and form shelf-transformed waters (STWs; Cottier et al. 2005). Local waters are formed in the inner part of the fjords, mainly due to the inflow of turbid meltwater from glaciated land (e.g. Syvitski et al. 1985, 1987). High turbidity and the consequential sedimentation result in the formation of unconsolidated sediment that could be easily resuspended by bottom currents and redeposited due to gravity flows (Zajączkowski and WłodarskaKowalczuk 2007). Therefore, the benthic fauna in the inner part of the fjords is exposed to chronic environmental disturbances that affect the standing stocks, diversity and taxonomic composition of the benthic fauna (e.g. WłodarskaKowalczuk et al. 2007). On the other hand, the outer parts of the fjords are impacted by STW, which creates more ameliorated environmental conditions and results in increases in the diversity and standing stocks of benthic organisms (e.g. Hald and Korsun 1997; Włodarska-Kowalczuk et al. 2007). 
According to Nilsen et al. (2016), Isfjorden is one of the fjord systems that is most affected by AW in Spitsbergen due to the deep trough at its entrance. Majewski and Zajączkowski (2007) noticed the intrusions of AW in central Adventfjorden (southern arm of Isfjorden) over the last 50 years, which caused pronounced oceanographic changes that affected the foraminiferal assemblages and mainly resulted in a higher biodiversity of foraminiferal fauna and a higher number of agglutinated species. A similar pattern was described by Łącka and Zajączkowski (2016) and Pawłowska et al. (2017a) in the Hornsund fjord (S Spitsbergen). The recent intensification of the inflow of AW to the Spitsbergen coasts has had an unexpectedly high impact on the oceanography of the fjords, sea-ice formation (Tverberg et al. 2014) and snow cover on the land (Comiso and Parkinson 2004). The impact affects the functional properties of the ecosystems of the fjords and leads to changes in productivity and biodiversity (e.g. Berge et al. 2005; Cottier et al. 2005). Recent studies have suggested that these changes may also have a tremendous influence on the seasonal variability in fjord systems (e.g. Zajączkowski et al. 2010a; Pawłowska et al. 2011).

Strong seasonal variation of environmental conditions controls the ecosystem functions of Arctic fjords (Loeng et al. 2005). Despite its importance, the seasonality in fjords has received little attention. Until now, only a few year-round studies that have focused on benthic foraminifera have been published. Jernas et al. (2018) studied the seasonality in the foraminiferal assemblages in Kongsfjorden and attributed the faunal variability to seasonal changes in the bottom water temperature, suspended solid concentrations and food availability. Korsun and Hald (2000) attributed the seasonal dynamics of the foraminiferal fauna in a glaciomarine fjord to environmental stress resulting from the discharge of meltwater and suspended solids. Additionally, Skirbekk et al. (2016) investigated the variations in the $\mathrm{Mg} / \mathrm{Ca}$ contents using foraminiferal tests and concluded that the calcification process is steered by seasonal changes in oceanographic conditions. However, the above studies comprised only surface sediments $(0-2 \mathrm{~cm})$, and living foraminifera can be observed down to $21 \mathrm{~cm}$ within the sediment (Zajączkowski et al. 2010b).

In this study, we investigated the horizontal and vertical seasonal patterns of the distribution of the benthic foraminiferal assemblages in Adventfjorden (Spitsbergen, Svalbard). The benthic foraminifera distribution and diversity patterns were described in relation to the steep environmental gradients resulting from the input of turbid riverine meltwater and the inflow of shelf-originated water masses.

\section{Materials and methods}

\section{Study area}

The study was conducted in Adventfjorden, the 8.3-kmlong and 3.4-km-wide southern arm of Isfjorden. The depth of Adventfjorden varies from $60 \mathrm{~m}$ in the central part to $100 \mathrm{~m}$ at the fjord mouth (Fig. 1). A wide outlet facilitates the exchange of water with the central basin of Isfjorden. In the innermost part of the fjord, two braided rivers, Adventelva and Longyearelva, form a $0.9-\mathrm{km}$-wide tidal flat. The prodelta slope reaches inclinations of $15-19^{\circ}$ and terminates at a depth of $30 \mathrm{~m}$. In the central fjord, the bottom continuously descends to a depth of $70 \mathrm{~m}$, with inclination of up to $8^{\circ}$, and in the deepest part of fjord, the inclination of the bottom decreases to $1^{\circ}$ (Zajączkowski 2008).

The climate in Adventfjorden is milder than in other regions at the same latitude due to the influence of the West Spitsbergen Current (WSC). According to Węsławski et al. (2011), in the warmest months (July and August), the air temperature reaches $5-6^{\circ} \mathrm{C}$, and in the coldest months (January to March), the air temperature falls to $-15^{\circ} \mathrm{C}$. In
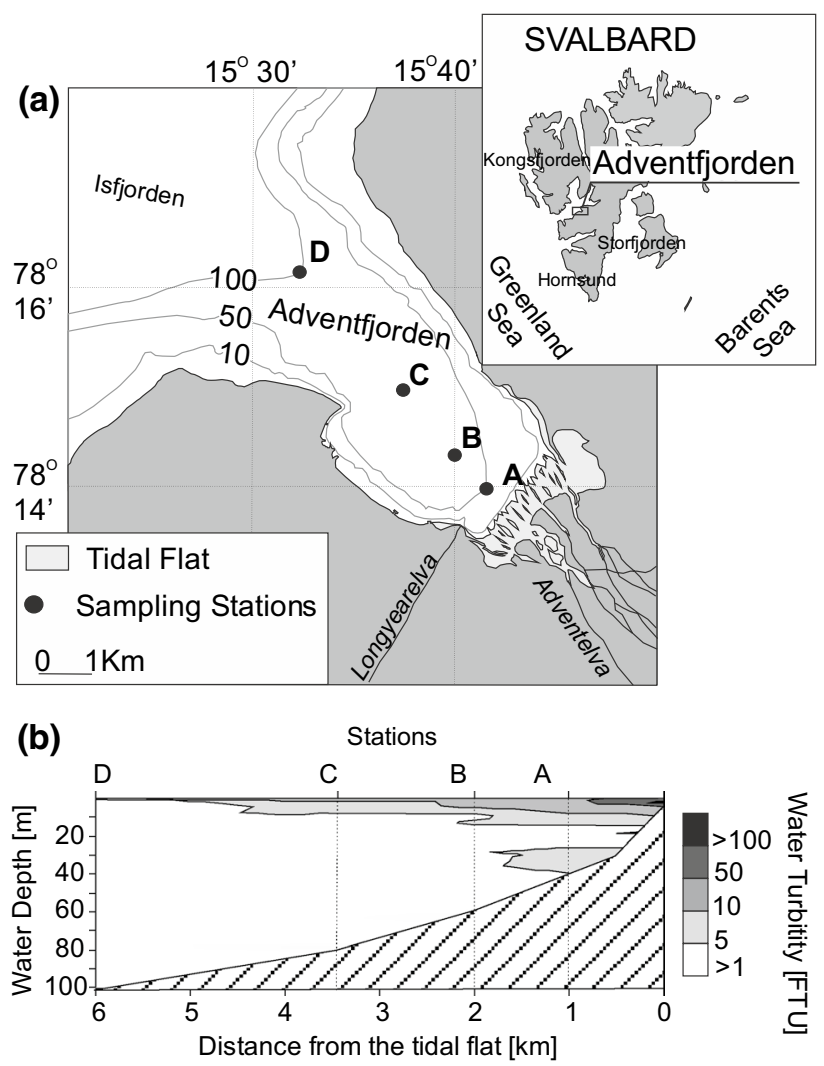

Fig. 1 a Study area and location of the sampling stations; AADV40, B-ADV60, C-ADV80 and D-ADV100; b water turbidity (FTU) profile measured in August 2015 
the twentieth century, Adventfjorden usually froze during the winter, and 1-m-thick fast ice formed (Wiktor 1999; Zajączkowski 2002); however, in recent years, the fjord has remained ice-free (Zajączkowski et al. 2010a).

The oceanography of Adventfjorden results from the inflow of highly saline and relatively warm water from southern Isfjorden and fresh and turbid meltwater from the land, causing stratification of the water column with a substantial brackish layer on the surface of the fjord. Isfjorden is supplied with Atlantic water that is transformed on the western shelf of Svalbard. According to Nilsen et al. (2016), Isfjorden receives substantial heat input from Atlantic water; therefore, even in April (the end of winter cooling), the water salinity and temperature reach 34.9 and $1.5^{\circ} \mathrm{C}$, respectively.

During the four months of the summer ablation season (June-September), the rivers transport meltwater and terrigenous material from glaciers located several kilometres from the seashore (Węsławski et al. 1999). Within this period, the average flows of Adventelva and Longyearelva reach $3.6 \mathrm{~m}^{3} \mathrm{~s}^{-1}$ and $2.04 \mathrm{~m}^{3} \mathrm{~s}^{-1}$, respectively. The mean concentrations of suspended solids transported in the river waters reach $307 \pm 177 \mathrm{mg}^{-1}$ and $471 \pm 221 \mathrm{mg}^{-1}$ in Adventelva and Longyearelva, respectively (Zajączkowski and Włodarska-Kowalczuk 2007). In the winter, both rivers freeze, and the delivery of sedimentary material stops. According to Zajączkowski et al. (2004), in Adventfjorden, the linear accumulation rate (LAR) of the sediment varies from $1.87 \mathrm{~cm} \mathrm{year}^{-1}$ in the inner fjord to $.07 \mathrm{~cm}_{\text {year }}{ }^{-1}$ at the mouth of the fjord. In the inner part of Adventfjorden, the steep inclination of the prodelta slope and high mineral flux (300-1000 $\mathrm{g} \mathrm{m}^{-2} \mathrm{day}^{-1}$ ) promote gravity-driven sediment redeposition, with turbidity currents above the bottom reaching velocities of $6-7 \mathrm{~cm} \mathrm{~s}^{-1}$. This phenomenon is also noted during winter storms that cause significant environmental disturbances. In the centre of the fjord, the energy of the turbidity currents weakens $\left(2-3 \mathrm{~cm} \mathrm{~s}^{-1}\right)$; however, transport of the clay fraction is observed near the bottom of the fjord mouth (Zajączkowski and Włodarska-Kowalczuk 2007). The particle flux measured in July 2002 by Zajączkowski and WłodarskaKowalczuk (2007) varied between $464.1 \mathrm{~g} \mathrm{~m}^{-2} \mathrm{day}^{-1}$ at the $40 \mathrm{~m}$ station, $29.4 \mathrm{~g} \mathrm{~m}^{-2} \mathrm{day}^{-1}$ at the $60 \mathrm{~m}$ station, down to $8.8 \mathrm{~g} \mathrm{~m}^{-2} \mathrm{day}^{-1}$ at the $80 \mathrm{~m}$ station and $9.5 \mathrm{~g} \mathrm{~m}^{-2} \mathrm{day}^{-1}$ at the $100 \mathrm{~m}$ station. The particle flux in winter (January 1996) decreases to $4.2 \mathrm{~g} \mathrm{~m}^{-2}$ day $^{-1}$ at the $40 \mathrm{~m}$ station and $3.5 \mathrm{~g} \mathrm{~m}^{-2}$ day $^{-1}$ at the $80 \mathrm{~m}$ station. According to Zajączkowski and Włodarska-Kowalczuk (2007), relatively high particle flux at the mouth of the fjord in summer might be a result of turbidity currents. According to Zajączkowski et al. (2010), the particle flux in May and November did not exceed $20 \mathrm{~g} \mathrm{~m}^{-2}$ day $^{-1}$ at the 40-m station.

\section{Sampling}

The sampling campaign was conducted during the four seasons of 2015: winter (January), spring (May), summer (August) and autumn (November). Anchored stations were located along the fjord axis at depths of $40 \mathrm{~m}, 60 \mathrm{~m}, 80 \mathrm{~m}$ and $100 \mathrm{~m}$ (Fig. 1a). The stations were located 1, 2, 3.5 and $6 \mathrm{~km}$ from the tidal flat, with GPS positioning of several metre accuracy.

The temperature, salinity and turbidity of the water column were measured with a Mini CTD Sensordata SD204 equipped with a turbidity sensor. Undisturbed $10-\mathrm{cm}$-long sediment cores were retrieved with a $4.5-\mathrm{cm}$-diameter gravity corer at the four stations in all seasons except for January, when samples were not taken at a depth of $100 \mathrm{~m}$. The transparent inner tube of the gravity corer allowed for the control of the undisturbed sediment surface. At each station, a single core was taken every season. The cores were kept in a vertical position before they were extruded with a piston and cut into $1-\mathrm{cm}$-thick slices.

Grain size analyses $(<2000 \mu \mathrm{m})$ were performed on the milled, freeze-dried bulk sediment samples with a Malvern Mastersizer 2000 laser particle analyser. The samples underwent ultrasound before analyses to avoid aggregation. The raw data were analysed with GRADISTAT v. 8.0 software (Blott and Pye 2001). Sediments were classified according to Udden (1914) and Wenthworth (1922).

Immediately after being cut into slices, samples for the foraminiferal analyses were treated with rose Bengal dissolved in $70 \%$ ethanol to distinguish the living specimens. The staining procedure recommended by Schönfeld et al. (2012) was applied. Samples were wet sieved through $500-\mu \mathrm{m}-$ and $100-\mu \mathrm{m}$-mesh-diameter sieves, dried and weighed. Whenever possible, 300 to 500 individuals of living and dead foraminifera were dry picked from each sample, identified to the lowest possible taxonomic level and counted. Samples with high quantities of foraminiferal tests were split using a dry microsplitter. According to Darling et al. (2016), the forms previously identified as Elphidium excavatum $f$. clavatum and E. excavatum $f$. selseyensis are genetically separated species. Following the suggestion of Darling et al. (2016), the names E. clavatum (formerly E. excavatum f. clavatum) and E. selseyense (E. excavatum f. selseyensis) are applied in this study. Two morphologically similar species, Textularia earlandii and Spiroplectammina biformis, were combined as Spiroplectammina spp.

The tests of the agglutinated specimens are opaque; therefore, they were excluded from the analysis of the living assemblages. Calcareous foraminifera with at least two stained chambers were classified as live organisms. The term "total" refers to the combined number of living 
and dead specimens and also includes the agglutinated foraminifera. The foraminiferal data were presented as the number of individuals per $1 \mathrm{~g}$ of dry sediment [ind $\mathrm{g}^{-1}$ ].

Bray-Curtis similarities between the samples were calculated based on the square-root transformed dataset. The similarity matrices were visualised with a non-metric multidimensional scaling (nMDS) plot. Data including only the living calcareous foraminifera were used for the multivariate analysis that was performed using PRIMER 6 software (Clarke and Warwick 1994). The multivariate analysis was carried out to verify the existence of similarities between stations from particular parts of the fjord in different seasons.

\section{Results}

\section{Water temperature, salinity and turbidity}

In the winter, the water temperature and salinity corresponded to those of the Arctic Water (AW) and winter cooled water (WCW). The water column was homogenous throughout the fjord with temperatures slightly below -1 ${ }^{\circ} \mathrm{C}$. However, the temperatures did not exceed the freezing point; thus, fast ice did not form. The water salinity was relatively stable and ranged from 32.5 at the surface of the inner fjord to 34.3 in the outer part (Fig. 2).

In May, the water masses in Adventfjorden were dominated by local waters (LW), with a near-bottom temperature slightly below $0{ }^{\circ} \mathrm{C}$ and a salinity of 34.5 (Fig. 2). However, in the central and inner fjord, brackish water appeared at the fjord surface, with the temperature and salinity reaching 2.5 ${ }^{\circ} \mathrm{C}$ and 32.2, respectively (Fig. 2).

In August, a layer of warm $\left(9{ }^{\circ} \mathrm{C}\right)$ brackish (5) water appeared on the fjord surface (Fig. 2). The outer fjord received STW with a temperature and salinity of $2{ }^{\circ} \mathrm{C}$ and 34.5, respectively (Fig. 2). During the summer, high water turbidity (up to 75 FTU) was noted at the surface of the inner fjord and decreased towards the fjord mouth (Fig. 1b).

In November, the outer and central parts of Adventfjorden were dominated by AW and STW, with the salinity exceeding 35 and the temperature varying between 3 and $4{ }^{\circ} \mathrm{C}$ (Fig. 2). The inflow of meltwater from the land was discontinued; thus, no brackish layer was observed on the fjord surface.

\section{Foraminiferal fauna}

In total, 27,039 individuals belonging to 69 species from 44 genera were identified; 43 species were calcareous, and 26 species were agglutinated (Fig. 3a; Online Resource 1).

The number of species at station ADV40 was the lowest among the stations, reaching only up to 5 species (Fig. 3a),
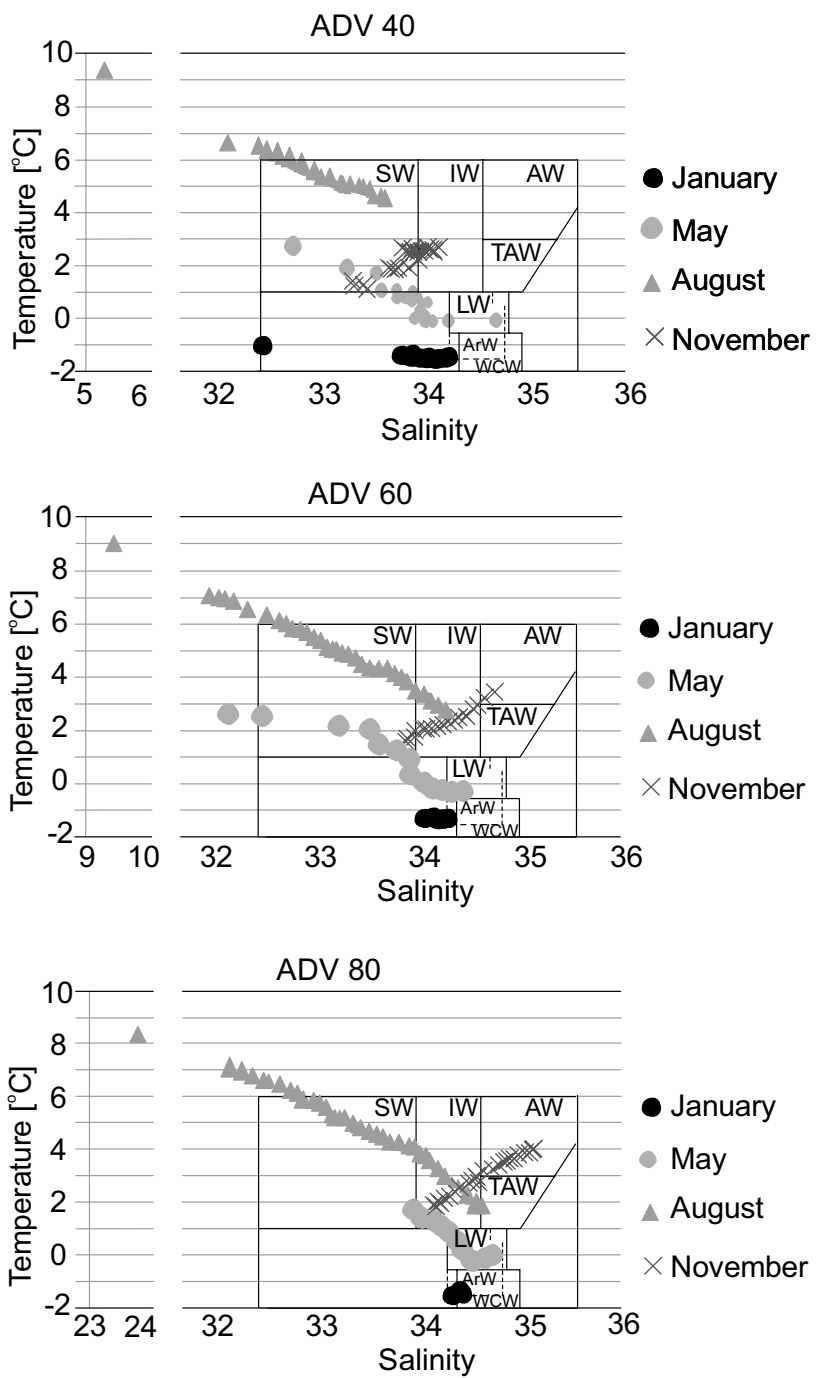

Fig. 2 Temperature-salinity diagrams at three stations in Adventfjorden measured during four seasons (January, May, August, November). The water masses were classified after Cottier et al. (2005). ArW Arctic water, $A W$ Atlantic water, $I W$ intermediate water, $L W$ local water, $S W$ surface water, $T A W$ transformed Atlantic water, $W C W$ winter cooled water; the dotted line marks the freezing point

except for May, when 8 calcareous and 6 agglutinated species were noted (Fig. 3a; Online Resource 1). The foraminiferal assemblage at station ADV40 was dominated by two taxa: calcareous Elphidium clavatum (Fig. 4) and agglutinated Spiroplectammina spp. Throughout the year, calcareous specimens dominated at the station (Fig. 3a). In January, the uppermost layers of sediment were barren or almost barren of foraminifera, and in May, only several specimens were found in the entire core. In August and November, the highest foraminiferal abundances (130 ind $\mathrm{g}^{-1}$ and 190 ind $\mathrm{g}^{-1}$, respectively) were noted at the sediment surface and noticeably decreased down the core (Fig. 5). The percentage of living calcareous individuals was highly variable. Throughout 

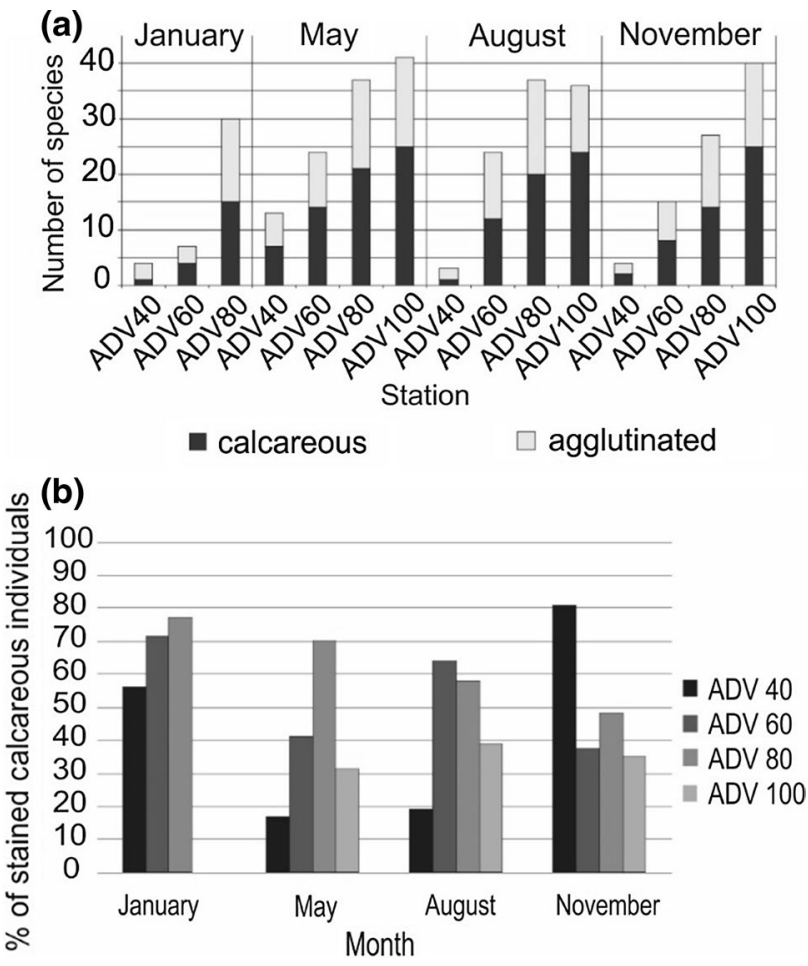

Fig. 3 a Number of species per station disaggregated on calcareous and agglutinated species; b Average percent of stained calcareous individuals in the cores

the year, living foraminifera were mostly observed in the sediment layers between 6 and $10 \mathrm{~cm}$, except for November, when stained individuals were also found at a depth of $2 \mathrm{~cm}$ (Fig. 4). The average percentage of stained individuals in the core at station ADV40 ranged throughout the year, between 18 and 19\% in May and August, 55\% in January and up to $80 \%$ in November (Fig. 3b). In January, between 6 and $10 \mathrm{~cm}$ of the core, the proportion of stained individuals in the total pool of calcareous foraminifera fluctuated from 30 to $80 \%$, with a maximum at $10 \mathrm{~cm}$ of the core. In May, stained foraminifera were observed only in one layer of the core at $8 \mathrm{~cm}$, and all were stained. In August, between 6 and $10 \mathrm{~cm}$, stained foraminifera accounted for more than $50 \%$ of the total pool of calcareous foraminifera. As in January, the maximum percentage $(100 \%)$ was observed at $10 \mathrm{~cm}$. In November, stained calcareous foraminifera were found in the first two centimetres of the core, where they accounted for 80 to $100 \%$ of all calcareous foraminifera. In addition, stained specimens were found at 7,9 and $10 \mathrm{~cm}$, where their percentage accounted for $100 \%$ of the total pool of calcareous foraminifera (Fig. 4).

The species richness at station ADV60 was slightly higher than that at station ADV40 (Fig. 3a). The number of species was lowest in January (7 species) and increased to 24 species in May and August (Fig. 3a). The foraminiferal assemblage at the station was dominated by calcareous $E$. clavatum and Cassidulina reniforme. Moreover, in August, large numbers of Melonis barleeanum, Stainforthia feylingi, and Spiroplectammina spp. were noted at the station (Fig. 4; Online Resource 1). Calcareous foraminifera species were dominant at this station throughout the year (Fig. 4). The upper sediment layer was barren of foraminifera in January, and the down-core distribution of specimens was random, with a maximum total abundance $\left(300\right.$ ind $\left.^{-1}\right)$ in the lowermost layer of the core. In May, the total number of foraminifera specimens at the sediment surface was low and increased down core, with a peak at $8 \mathrm{~cm}$ sediment depth $\left(510\right.$ ind $\mathrm{g}^{-1}$; Fig. 4). In August, the vertical distribution of foraminifera showed the opposite trend: the highest total abundance was observed at the sediment surface and decreased down core from 560 ind $\mathrm{g}^{-1}$ to 100 ind $\mathrm{g}^{-1}$. In November, the upper part of the core was almost barren of foraminifera, and the highest number of specimens $\left(650\right.$ ind $\left.^{-1}\right)$ was noted at the bottom of the core (Fig. 4).

The highest average percentage of stained specimens was noted in January (72\%) and further decreased, reaching $41 \%, 64 \%$ and $38 \%$ in May, August and November, respectively (Fig. 3b). During the year, stained foraminifera were observed throughout the entire length of the cores, but their percentages fluctuated largely between the individual layers (Fig. 4). In January, stained individuals were found in all core layers except at 1 and $4 \mathrm{~cm}$. The highest percentages of living foraminifera, varying between 85 and $100 \%$, were found at 2-3, 5 and $9-10 \mathrm{~cm}$. In May, stained foraminifera were observed in all layers of the core. The maximum percentage (80\%) was observed in the first centimetre, and the minimum (25\%) was observed in $2 \mathrm{~cm}$. In the remaining layers, the core percentage of stained individuals ranged from 40 to $55 \%$. In August, stained foraminifera were observed in all core layers, with a maximum in the first two centimetres of the core (up to $85 \%$ ) and a minimum at $4 \mathrm{~cm} \mathrm{(35 \% ).} \mathrm{In} \mathrm{the}$ layers below, the proportion of stained individuals ranged from 40 to $65 \%$. In November, stained foraminifera were not observed in the 2 and $5 \mathrm{~cm}$ layers. The percentage of living foraminifera reached a maximum at $3-4 \mathrm{~cm}(100 \%)$ and decreased below $5 \mathrm{~cm}$ depth, ranging from 30 to $50 \%$ (Fig. 5).

The foraminiferal abundance and species number at station ADV80 were relatively high compared to the inner and central stations. The number of species increased from 30 in January to 37 in May and August and decreased again to 26 in November (Fig. 3a). The foraminiferal assemblage at station was dominated by Nonionellina labradorica and Spiroplectammina spp. throughout the year; however, in August and November, high numbers of Cribrostomoides crassimargo appeared in the upper $5 \mathrm{~cm}$ of the sediment (Fig. 4; Online Resource 1). In all studied seasons, agglutinated foraminifera dominated at the station (Fig. 4). In January, the majority of the living and dead individuals 


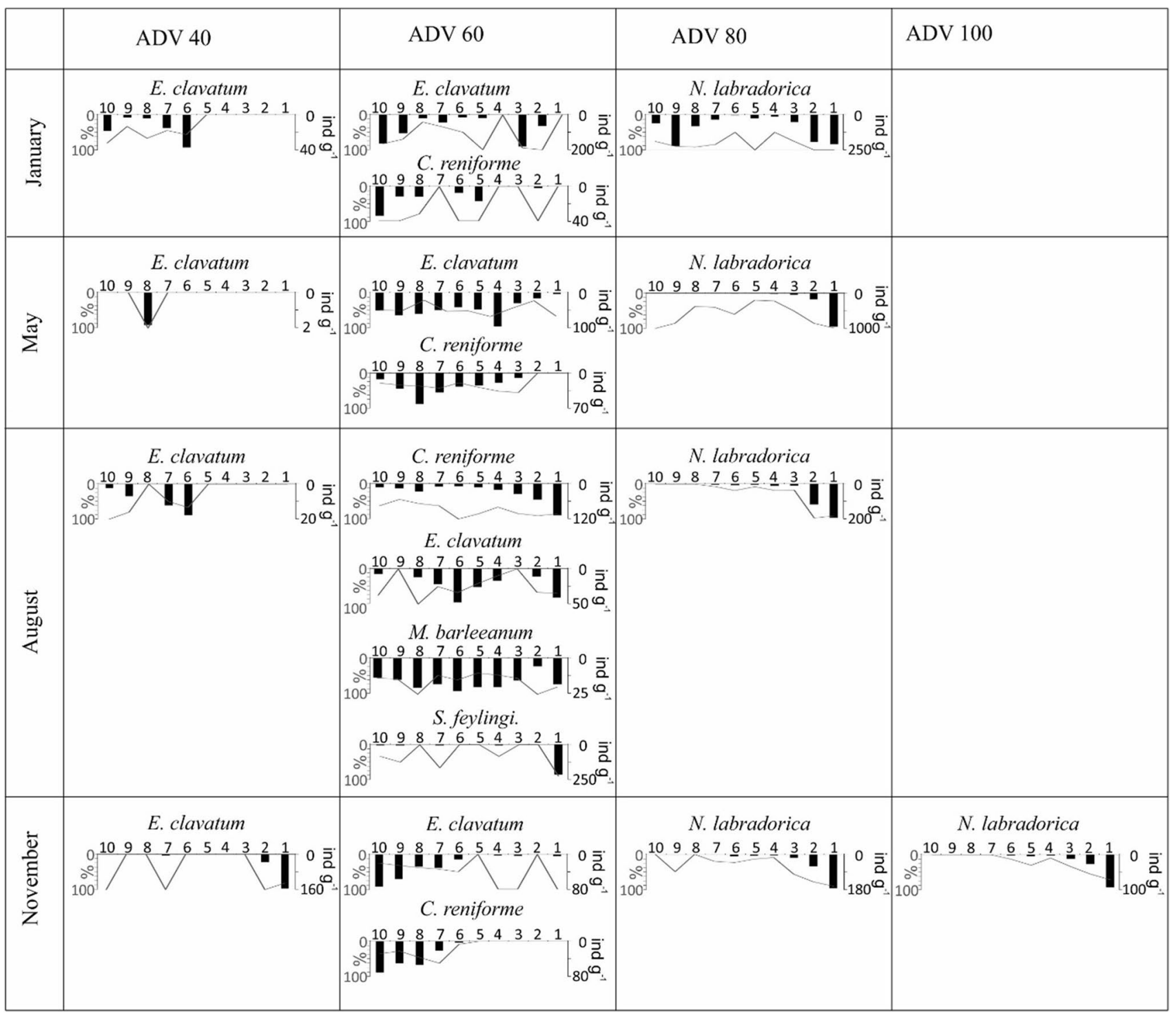

Fig. 4 Total amount of dominating calcareous species calculated per $1 \mathrm{~g}$ of dry sediment and percent of stained individuals among them (line). The chosen species exceeded $10 \%$ of the total number of speci-

(up to 1200 ind $\mathrm{g}^{-1}$ ) were found in the lowermost part of the core. The highest total number of foraminifera was noted in May (up to 1600 ind g ${ }^{-1}$ ), while in August and November, the number did not exceed 600 ind g $^{-1}$ (Fig. 4). The average percentage of stained individuals in the core at station ADV80 ranged from $48 \%$ in January to $70 \%$ in May and 58\% in August to $80 \%$ in November (Fig. 3b). In all seasons, the highest percentages (up to 100\%) of stained foraminifera were observed between 1 and $3 \mathrm{~cm}$ and decreased down core. In January, the percentages of living specimens below $3 \mathrm{~cm}$ varied from 45 to $85 \%$. In the remaining seasons, the percentages were lower, ranging from 20 to 35\% in May, 6 and 40\% in August, and 10 and $25 \%$ in November (Fig. 5). mens found at each station. The species are ordered from most abundant to least abundant

The number of foraminiferal species at station ADV100 was highest among the studied stations, reaching 41 species in May and 36 and 40 species in August and November, respectively (Fig. 5a). The foraminiferal assemblage at this station was dominated by agglutinated species: Spiroplectammina spp., Recurvoides turbinata and C. crassimargo (Online Resource 1). In November, Reophax fusiformis and $N$. labradorica also appeared as co-dominant species (Fig. 4; Online Resource 1). The total foraminiferal abundance was highest in May (up to $1400 \mathrm{ind} \mathrm{g}^{-1}$ ) and decreased in August and November (down to 400 ind $\mathrm{g}^{-1}$ and 100 ind $\mathrm{g}^{-1}$, respectively; Fig. 5). The only exception was two peaks of abundance that were noted in August at depths of 6 and $8 \mathrm{~cm}$, reaching 1800 ind $\mathrm{g}^{-1}$ and 1350 ind $^{-1}$, respectively 
Fig. 5 Distribution of living and dead foraminifera specimens in the sediment and percentage of stained individuals among calcareous specimens

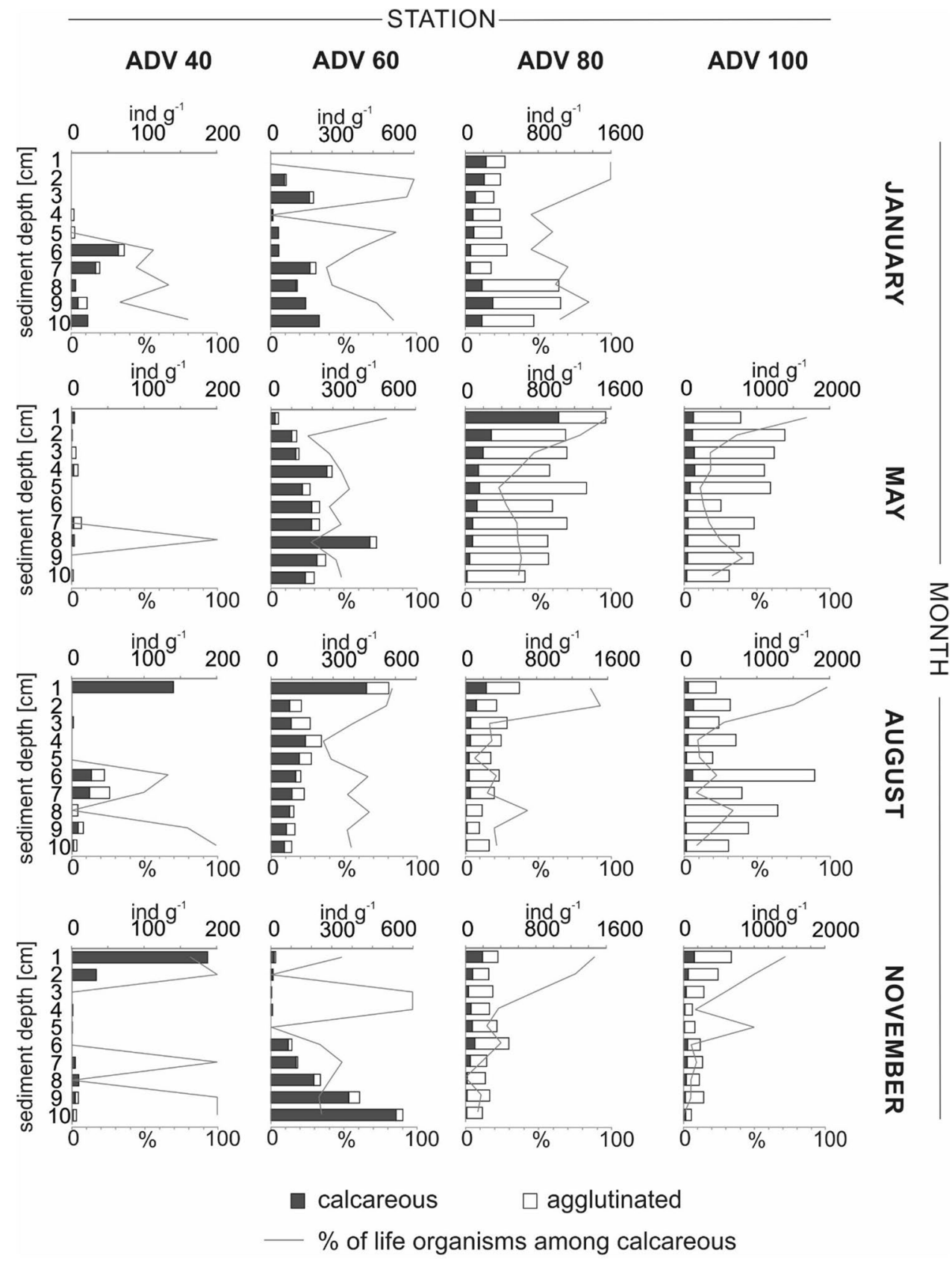

(Fig. 4). The variation of the average percentage of stained individuals in the core at station ADV100 was much lower than the variation at the other stations. Its values ranged from $32 \%$ in May to 35\% in November up to 39\% in August (Fig. 3b). The highest percentages of stained individuals were observed in the uppermost layers of the cores regardless of season, reaching $85 \%$ in May, 95\% in August and $70 \%$ in November (Fig. 5). In the lower layers, in May and August, the percentage of stained individuals ranged between 10 and 30\%, and in November, it did not exceed $10 \%$, except for one peak at $5 \mathrm{~cm}$ when it increased to $50 \%$ (Fig. 5).

\section{Multivariate analysis (Bray-Curtis similarity)}

The analysed samples formed three groups on the nMDS plot, corresponding to the outer, central and inner fjord (Fig. 6). The similarity analysis showed a high resemblance between the samples from stations ADV80 and ADV100; thus, these samples formed one distinct group corresponding to the outer fjord (Fig. 6). The second group comprised samples from station ADV60 (central fjord). The samples representing the innermost station, ADV40, in January, August and November were tightly grouped. The only exception was the sample representing station 
Fig. 6 Bray-Curtis similarities of the foraminiferal assemblages between stations for living specimens. $J$ January, $M$ May, $A$ August, $N$ November

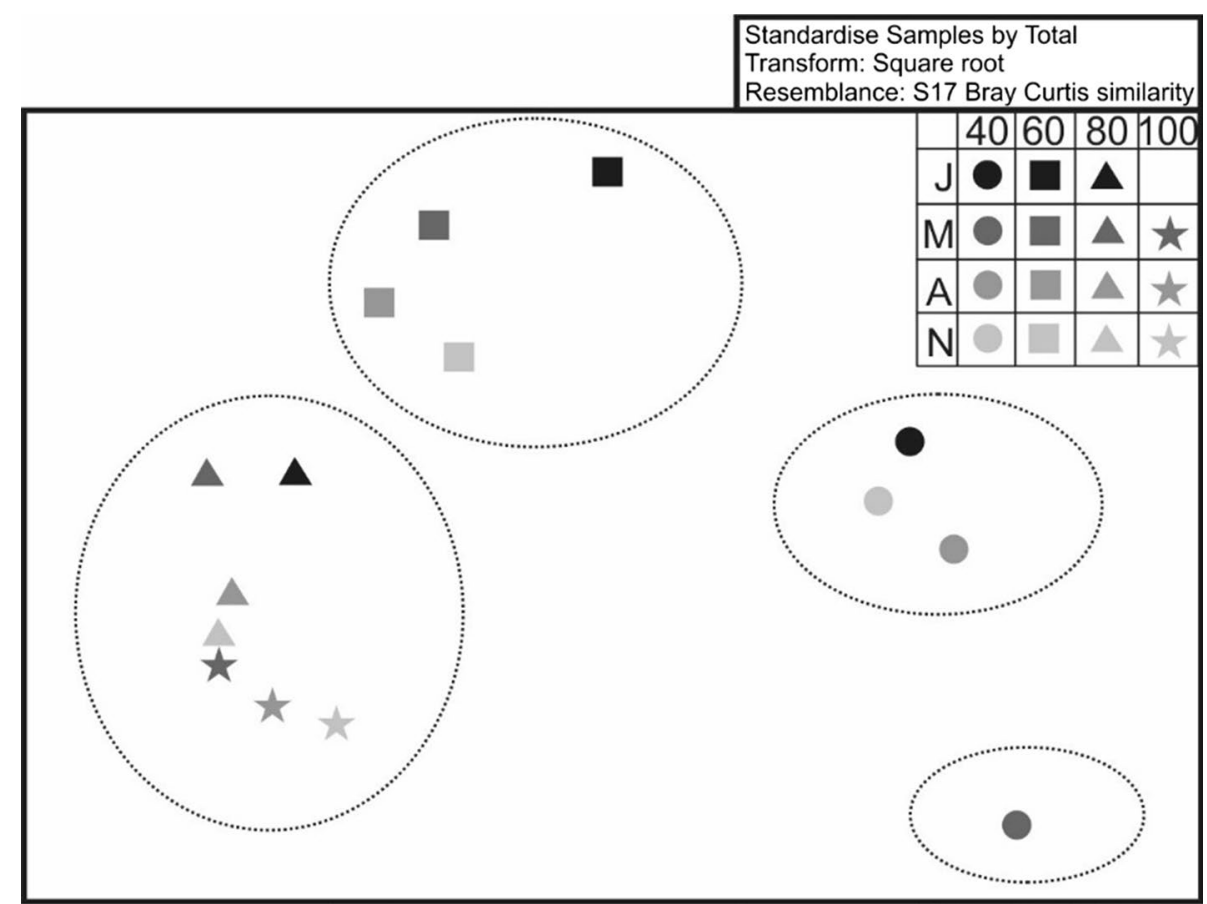

ADV40 in May, which was clearly separated from the other samples (Fig. 6).

\section{Discussion}

The distribution of foraminiferal assemblages in Adventfjorden reflected the environmental gradients from the inner to the outer fjord. The spatial variability of the environmental conditions in Adventfjorden results from both the riverine input of turbid meltwater (e.g. Zajączkowski and WłodarskaKowalczuk 2007) and the inflow of STW (e.g. Majewski and Zajączkowski 2007). The environmental gradients are also clearly reflected in the macro- and meiobenthic communities, which respond to environmental disturbances in the proximity of the tidal flat (Pawłowska et al. 2011). The rivers mainly impact the innermost part of Adventfjorden, whereas the outer fjord is under the influence of STW from central Isfjorden.

The innermost station (ADV40) was located at the edge of the prodelta slope and was characterised by frequent gravity flows and high sediment deposition rates (Zajączkowski et al. 2010a), which resulted in the low abundance and diversity of foraminiferal fauna observed throughout the year (Figs. 3, 5). The dominant component of the assemblage was E. clavatum (Figs. 4, 6), which is an opportunistic species that is frequently noted in disturbed environments near tidewater glaciers in Svalbard and Novaya Zemlya (e.g. Hald et al. 1994; Hald and Korsun 1997; Korsun and Hald 2000; Łącka and Zajączkowski 2016). Majewski and Zajączkowski
(2007) linked the dominance of E. clavatum in the inner Adventfjorden with variable environmental conditions mainly caused by high water turbidity and high sedimentation rates.

The foraminiferal community at station ADV60 was more abundant and diverse than at station ADV40 (Figs. 3, 5), and the assemblage was co-dominated by E. clavatum and C. reniforme (Figs. 4, 6). According to Hald and Korsun (1997), C. reniforme and E. clavatum co-dominated the assemblages in the innermost parts of the fjords; however, $C$. reniforme commonly replaces $E$. clavatum at the transition from proximal to distal zones, where the salinity fluctuates less and is often higher than the salinity near tidewater glaciers (Łącka and Zajączkowski 2016).

On the other hand, the apparent sign of the presence of STW at station ADV60 was the peak of the abundance of $M$. barleeanum (Fig. 4), followed by a relatively high foraminiferal diversity observed in August (Fig. 3). M. barleeanum is an Arctic-boreal species associated with AW (Hald and Steinsund 1996; Jennings et al. 2004) and is commonly found in contemporary Norwegian fjords (e.g. Husum and Hald 2004). In Svalbard, M. barleeanum was found in Storfjordrenna (Łącka et al. 2015) and on the West Spitsbergen Shelf (Jernas et al. 2013). The occurrence of M. barleeanum was also linked to high productivity (Schmiedl and Mackensen 1997) and the presence of slightly altered organic matter (Caralp 1989). Therefore, the presence of a high number of M. barleeanum in Adventfjorden might result from both the availability of slightly decomposed organic matter (e.g. Zajączkowski et al. 2010a) and the seasonal intensification 
of the inflow of STW. The latter explanation is in accordance with Majewski and Zajączkowski (2007), who observed variations in the extent of STW in Adventfjorden over the last 50 years that were reflected in changes in the foraminiferal assemblages.

The impact of STW was most apparent in the outer Adventfjorden (stations ADV80 and ADV100) and was expressed as high foraminiferal abundance and diversity (Figs. 3, 5), a high percentage of agglutinated taxa (Fig. 5) and the pronounced presence of species associated with waters of Atlantic origin, e.g. N. labradorica (Fig. 4). It is probably why the nMDS plot (Fig. 6) shows a high resemblance between the samples from these stations. In the fjords of Svalbard and Novaya Zemlya, N. labradorica usually occupies outer glacier-distal settings that are influenced by warm and saline water (e.g. Hald and Korsun 1997; Korsun and Hald 1998; Pogodina 2005). Moreover, high occurrences of $N$. labradorica were found in the Barents Sea in the highly productive zones near the polar front and/or the sea-ice edge (Hald and Steinsund 1996).

The most prominent feature of the foraminiferal assemblages in the outer Adventfjorden was the year-round dominance of agglutinated species, which made up $90 \%$ of the total foraminiferal abundance (Fig. 5). Additionally, Majewski and Zajączkowski (2007) noted a markedly high percentage of agglutinated taxa in the outer Adventfjorden during the summer of 2004. Such a high percentage of agglutinated foraminifera is unusual when compared to other Spitsbergen fjords. According to Hald and Korsun (1997), the agglutinated taxa in the fjords of western and northern Spitsbergen did not exceed $50 \%$ of the foraminiferal assemblages. Majewski and Zajączkowski (2007) attributed the high abundance of agglutinated foraminifera to the poor preservation of the calcareous tests due to intensive organic matter decay, which led to the lowering of the $\mathrm{pH}$ and the dissolution of the calcareous tests. According to Pawłowska et al. (2017b), the decay of sedimentary organic matter in Adventfjorden is more intensive during the summer than in the other seasons, which might affect carbonate preservation. However, the signs of intensive organic matter decay were observed only during the summer, whereas the percentage of agglutinated foraminifera remained high in all seasons. Moreover, the tests of calcareous foraminifera showed no signs of severe dissolution. Schröder-Adams et al. (1990) linked the high abundance of arenaceous fauna with waters influenced by meltwater, characterised by reduced salinity and increased sedimentation rate. However, in Spitsbergen fjords, the number of agglutinated foraminifera generally increases towards the fjord mouth, and the lowest abundances of agglutinated taxa are observed close to the sources of turbid meltwater outflows (e.g. Hald and Korsun 1997). Therefore, the reasons for the exceptionally high abundances of agglutinated taxa remain unclear.
The down-core distribution of living foraminifera showed clear spatial variability. Living specimens were abundant down to sediment depths of $10 \mathrm{~cm}$ (Figs. 4, 5), which contradicts the opinion that the majority of living foraminifera are found on the sediment surface (e.g. Schönfeld et al. 2012). In the outer part of Adventfjorden (ADV100 and ADV80), the majority of the stained specimens were concentrated in the upper $4 \mathrm{~cm}$ of the sediment (Fig. 5), whereas in the central and inner stations (ADV60 and ADV40), the uppermost layers were often barren or almost barren of living foraminifera, regardless of season (Fig. 5). Previous studies that considered the vertical distribution of foraminifera suggested that there is no universal down-core distribution pattern of certain taxa (Murray 2006), and the distribution may vary through time, even at a single site (Jorissen 1999 and references therein). In our study, the seasonal variation of the vertical distribution of foraminifera was observed at each study site, which may result from both seasonal changes of environmental conditions and some stochastic noise coming from the lack of replicates.

The vertical distribution patterns of foraminifera are mainly a result of active migration in response to physical and chemical gradients in sediment (e.g. Alve and Bernhard 1995). Food availability and oxygen concentration are listed among the most important factors determining the occurrence of foraminifera in the subsurface sediment layers. However, in the inner Adventfjorden, one of the major factors affecting foraminifera distribution is high sedimentation rates, which lead to the burial of foraminifera specimens. Laboratory experiments showed that foraminifera may survive even in deeper, anoxic sediment layers and actively migrate upwards when buried (Moodley et al. 2000). It is likely that in the inner Adventfjorden, the foraminifera are buried and/or removed from the upper sediment layers, whereas in the outer part of the fjord, the foraminiferal communities are less impacted by sedimentation; therefore, the majority of them are concentrated in the surface sediments where microenvironmental conditions are more favourable.

The down-core distribution of foraminifera may also be affected by the postmortem decay of cement in the agglutinated tests and the dissolution of calcareous tests under low $\mathrm{pH}$. However, in Adventfjorden, there were no signs of severe test degradation, regardless of season. Majewski and Zajączkowski (2007) suggested that the dissolution of calcareous tests was due to a low $\mathrm{pH}$; however, the latter was not confirmed by further studies (e.g. Pawłowska et al. 2017).

The observations from Hornsund (Zajączkowski et al. 2010b) and Adventfjorden (Szymańska et al. 2017) showed that for selected taxa, the depth of maximum abundance is likely to be fixed, e.g. for E. clavatum it is ca. $4-6 \mathrm{~cm}$, and for $N$. labradorica, it is ca. $0-2 \mathrm{~cm}$. According to Jorissen (1999), the vertical distribution of foraminiferal species is 
strongly related to the species' ecology and food availability: the species living at the sediment surface feed on labile particulate organic matter, whereas the species living in the sediment feed on bacterially mediated labile organic matter (Levinton 1989). Foraminifera may migrate in the sediment in search of the optimal microhabitat (i.e. the preferable combination of physical, chemical and biological conditions). Therefore, the vertical distribution of foraminifera in Adventfjorden most likely resulted from the microhabitat preferences of certain species. However, in the inner fjord, high sediment accumulation/deposition may influence the vertical distribution of foraminifera via the rapid burial of specimens (Zajączkowski et al. 2010b).

The foraminiferal community in Adventfjorden showed clear seasonal variability in terms of abundance and species number. The seasonal development of the foraminiferal assemblages in Adventfjorden followed the patterns previously described in the fjords of Svalbard (e.g. Korsun and Hald 2000; Jernas et al. 2018), which were steered by seasonal changes in meltwater and suspension delivery and food availability controlled by pelagic production (e.g. Zajączkowski et al. 2010a). Seasonal changes in the macroand meiobenthic community (foraminifera excluded) in Adventfjorden were described by Pawłowska et al. (2011). The highest biomass, abundance and diversity of the meiobenthos occurred in the spring during a phytoplankton bloom. During the summer, the intense supply of turbid meltwater resulted in the suppression of primary production and an increased level of environmental disturbance, leading to a remarkable decrease in the meiobenthic biomass and abundance. Noticeably, both the biomass and abundance of the meiofauna were relatively high in the autumn and winter, which probably resulted from the availability of food in the form of resuspended organic particles and/or organic matter deposited in the sediments and the low level of environmental disturbance.

The total (i.e. living and dead) foraminiferal communities in Adventfjorden followed the patterns described above, revealing peaks in abundance and diversity in the spring followed by decreases in the summer. The only exception was the innermost station, ADV40, where the foraminiferal abundance was minimal in May (Fig. 4), which most likely resulted from sediment redeposition. The only living foraminifera were E. clavatum found in the layers $8 \mathrm{~cm}$ under the sediment surface. The uniqueness of this station was also confirmed by the Bray-Curtis similarity plot (Fig. 6), where the station ADV40 in May was clearly separated from the other samples. However, the spring increase in the total foraminiferal abundance was followed by a decrease in the number of stained individuals. According to Pawłowska et al. (2017b), the increases in the foraminiferal abundance and diversity observed in the spring were followed by decreases in the average test size, which resulted from the presence of many juveniles. However, the immature individuals that grow during the primary production maximum in the spring may later wither under less favourable environmental conditions that occur in the summer and continue in the autumn and winter (Łącka and Zajączkowski 2016). It is likely that in Adventfjorden, the withering of juveniles may occur even in spring. The lack of sea-ice cover observed in recent years has accelerated the phytoplankton bloom and the growth of planktonic and benthic organisms (Zajączkowski et al. 2010a). Therefore, the peak of living foraminifera may be recorded in the early spring. A decreasing trend was observed in the total foraminiferal abundance and diversity in the summer (Figs. 4, 5). However, the summer decrease in living fauna was observed only in the outer stations (ADV80 and ADV100) and in the innermost station, ADV40. In the outer fjord, a low number of living foraminifera may be attributed to the withering of the individuals that started to grow after the spring phytoplankton bloom and continued during the summer. However, the low number of stained individuals in the inner fjord most likely resulted from the intensive river discharge and the settling of mineral matter, resulting in the burial of the foraminifera and/or the removal of foraminifera individuals by gravity flows. On the other hand, the number of living foraminifera increased noticeably during the summer at station ADV60, which may be a result of the occurrence of large numbers of $M$. barleeanum and S. feylingi, which made up $25 \%$ and $33 \%$ of the living foraminifera, respectively (Fig. 4). This variation in faunal composition may be an effect of the change in environmental conditions, e.g. the increased inflow of AW and/or the natural patchiness of the benthic fauna. To confirm the latter, further studies comprising the analysis of sample replicates are required.

Moreover, the total abundances in the autumn and winter were relatively high at all investigated stations, as previously observed in the case of meiobenthic taxa (Pawłowska et al. 2011). Additionally, the number and percent of living fauna was among the highest observed at each station. The latest data from Kongsfjorden showed that benthic foraminifera are not dormant and actively feed during the polar night (Kniazeva and Korsun 2016). Additionally, Korsun and Hald (2000) noted that the foraminiferal abundance in Tempelfjorden was high in the winter, which was attributed to a reduction in environmental stress. Similar conclusions were reached by Zajączkowski et al. (2010a) and Pawłowska et al. (2011), who attributed the high meiofaunal biomass and abundance to both the minimal delivery of sediment from suspension and the availability of organic matter, which was mainly slightly decomposed material deposited in the sediments. 


\section{Summary}

The foraminiferal assemblages in Adventfjorden clearly reflected the spatial variability of the environmental conditions, from the innermost part of the fjord that was strongly impacted by riverine input and high sediment loads to the outer part that was mainly shaped by the inflows of STW from the central basin of Isfjorden.

The inner and central fjord were characterised by low foraminiferal abundance and diversity and the pronounced presence of calcareous glaciomarine taxa, especially $E$. clavatum and $C$. reniforme. On the other hand, the peak in $M$. barleeanum that was observed in the central Adventfjorden may indicate the seasonal variability in the extent of STW from central Isfjorden. The foraminiferal assemblages in the outer Adventfjorden reflected the impact of STW and were characterised by high abundance, diversity and dominance of the species considered to be AW indicators, such as $N$. labradorica, A. cassis and R. turbinata, staying in the few uppermost layers of sediment.

The down-core distribution of living foraminifera varied along the fjord axis. In the inner fjord, the majority of living individuals were found between 4 and $10 \mathrm{~cm}$ sediment depths, whereas in the outer part, living specimens were concentrated in the uppermost $2 \mathrm{~cm}$ of sediment. This distribution mainly resulted from the ecological preferences of the taxa that were dominant in each part of the fjord and their consequent downward migration in search of optimal microhabitats. Moreover, the distribution of the foraminiferal fauna in the inner fjord was impacted by high sedimentation that caused the rapid burial of the tests.

Despite the fact that the taxonomic composition of the foraminiferal assemblages remained stable throughout the year, the foraminiferal abundance and diversity varied seasonally. The changes were mainly driven by the variation in food supply, the level of environmental disturbance and the impact of STW on the central and outer fiords. The foraminiferal abundance peaked in the spring during the period of maximum food supply and further decreased in the summer and autumn. In the spring, the delivery of fresh, phytoplankton-derived organic matter followed by the relatively low settling of mineral matter induced the fast growth of foraminiferal juveniles. However, many of the juveniles may later wither under less favourable conditions during the summer and autumn. Moreover, the foraminiferal abundance observed in the winter was relatively high, which supported the previous suggestions (cf. Hald and Korsun 2000; Kniazeva and Korsun 2016) that benthic foraminifera do not remain dormant during the polar night, and the majority of the mature specimens can overwinter because of sufficient organic matter stocks and year-long ice-free conditions.
Acknowledgements Funding of this study was provided by the National Science Centre in Poland through projects 2013/11/B/ ST10/00276 and 2014/15/N/ST10/05115.

\section{Compliance with ethical standards}

Conflict of interest The authors declare that they have no conflict of interest.

OpenAccess This article is distributed under the terms of the Creative Commons Attribution 4.0 International License (http://creativeco mmons.org/licenses/by/4.0/), which permits unrestricted use, distribution, and reproduction in any medium, provided you give appropriate credit to the original author(s) and the source, provide a link to the Creative Commons license, and indicate if changes were made.

\section{References}

Alve E, Bernhard JM (1995) Vertical migratory response of benthic foraminifera to controlled oxygen concentrations in an experimental mesocosm. Mar Ecol Prog Ser 116:137-151

Berge J, Johnsen G, Nilsen F, Gulliksen B, Slagstad D (2005) Ocean temperature oscillations enable reappearance of blue mussels Mytilus edulis in Svalbard after a 1000 year absence. Mar Ecol Prog Ser 303:167-175

Blott SJ, Pye K (2001) GRADISTAT: a grain size distribution and statistics package for the analysis of unconsolidated sediments. Earth Surf Proc Land 26:1237-1248

Caralp MH (1989) Abundance of Bulimina exilis and Melonis barleeanum: relationship to the quality of marine organic matter. Geo-Marine Lett 9:37-43

Clarke KR, Warwick RM (1994) An approach to statistical analysis and interpretation. Change in marine communities. 2nd edn, PRIMERE, Ltd., Plymouth Marine Laboratory, Plymouth, pp. 1-176

Comiso JC, Parkinson CL (2004) Satellite observed changes in the Arctic. Phys Today 57:38-44

Cottier F, Tverberg V, Inall M, Svendsen H, Nilsen F, Griffiths C (2005) Water mass modification in an Arctic fjord through cross-shelf exchange: the seasonal hydrography of Kongsfjorden. Svalbard. J Geophys Res 110:C12005

Darling KF, Schweizer M, Knudsen KL, Evans KM, Bird C, Roberts A, Filipsson HL, Kim J-H, Gudmundsson G, Wade CM et al (2016) The genetic diversity, phylogeography and morphology of Elphidiidae (foraminifera) in the Northeast Atlantic. Mar Micropaleontol 129:1-23

Hald M, Korsun S (1997) Distribution of modern benthic foraminifera from fjords of Svalbard, European Arctic. J Foraminifer Res 27:101-122

Hald M, Steinsund PI (1996) Benthic foraminifera and carbonate dissolution in the surface sediments of the Barents and Kara Seas. Surface-sediment composition and sedimentary processes in the central Arctic Ocean and along the Eurasian Continental Margin. Ber Polarforsch 212:285-307

Hald M, Steinsund PI, Dokken T, Korsun S, Polyak L, Aspeli R (1994) Recent and late quaternary distribution of Elphidium excavatum f. clavatum in Arctic seas. Cushman Found Spec Pub 32:141-153

Husum K, Hald M (2004) A continuous marine record 8000-1600 cal. yr BP from the Malangenfjord, north Norway: foraminiferal and isotopic evidence. The Holocene 14:877-887

Jennings AE, Weiner NJ, Helgadottir G, Andrews JT (2004) Modern foraminiferal faunas of the southwestern to northern Iceland shelf: oceanographic and environmental controls. J Foraminifer Res 34:180-207 
Jernas PE, Klitgaard-Kristensen D, Husum K, Wilson L, Koç N (2013) Palaeoenvironmental changes of the last two millennia on the western and northern Svalbard shelf. Boreas 42:236-255

Jernas PE, Klitgaard-Kristensen D, Husum K, Koç N, Tverberg V, Loubre P, Prins M, Dijkstra N, Gluchowska M (2018) Annual changes in Arctic fjord environment and modern benthic foraminiferal fauna: evidence from Kongsfjorden, Svalbard. Global Planet Change 163:119-140

Jorissen FJ (1999) Benthic foraminiferal microhabitats below the sediment-water interface. Modern foraminifera. Springer, Dordrecht, pp 161-179

Kniazeva O, Korsun S (2016) The long polar night: do benthic foraminifera feed? Book of abstracts, The Batsheva de Rotschild Workshop: live foraminifera as a new model system for monitoring and reconstructing marine environments. Eilat, Israel

Korsun S, Hald M (1998) Modern benthic foraminifera off Novaya Zemlya tidewater glaciers, Russian Arctic. Arctic Alpine Res 30:61-77

Korsun S, Hald M (2000) Seasonal dynamics of benthic foraminifera in a glacially fed fjord of Svalbard, European Arctic. J Foraminifer Res 30:251-271

Łącka M, Zajączkowski M (2016) Does the recent pool of benthic foraminiferal tests in fjordic surface sediments reflect interannual environmental changes? The resolution limit of the foraminiferal record. Ann Soc Geol Pol 86:59-71

Łącka M, Zajączkowski M, Forwick M, Szczuciński W (2015) Late Weichselian and Holocene palaeoceanography of Storfjordrenna, southern Svalbard. Clim Past 11:587-603

Levinton JS (1989) Deposit feeding and coastal oceanography. Ecology of marine deposit feeders. Springer, New York, NY, pp 1-23

Loeng H, Brander K, Carmack E, Denisenko S, Drinkwater K, Hansen B, Kovacs K, Livingston P, McLaughlin F, Sakshaug E (2005) Marine systems. Arctic climate impact assessment 453538

Mackensen A, Sejrup HP, Jansen E (1985) The distribution of living benthic foraminifera on the continental slope and rise off southwest Norway. Mar Micropaleontol 9:275-306

Mackensen A, Grobe H, Kuhn G, Fu DK (1990) Benthic foraminiferal assemblages from the eastern Weddell Sea between 68 and $73^{\circ} \mathrm{S}$ : distribution, ecology and fossilization potential. Mar Micropaleontol 16:241-283

Majewski W, Zajaczkowski M (2007) Benthic foraminifera in Adventfjorden, Svalbard: last 50 years of local hydrographic changes. J Foraminifer Res 37:107-124

Malmgren BA, Haq BU (1982) Assessment of quantitative techniques in paleobiogeography. Mar Micropaleontol 7:213-236

Moodley L, Chen G, Heip C, Vincx M (2000) Vertical distribution of meiofauna in sediments from contrasting sites in the Adriatic Sea: clues to the role of abiotic versus biotic control. Ophelia 53:203-212

Murray JW (2006) Ecology and applications of benthic foraminifera. Cambridge University Press, Cambridge

Nilsen F, Skogseth R, Vaardal-Lunde J, Inall M (2016) A simple shelf circulation model: intrusion of Atlantic Water on the West Spitsbergen Shelf. J Physical Oceanogr 46:1209-1230

Pawłowska J, Zajączkowski M, Szczuciński W, Zaborska A, Kucharska M, Jernas P, Forwick M (2017a) The influence of Coriolis force driven water circulation on the palaeoenvironment of Hornsund ( $S$ Spitsbergen) over the last century. Boreas 46:737-749

Pawłowska J, Łącka M, Kucharska M, Szymańska N, Koziorowska K, Kuliński K, Zajączkowski M (2017b) Benthic foraminifera contribution to fjord modern carbon pools: a seasonal study in Adventfjorden, Spitsbergen. Geobiology 15:704-714

Pawłowska J, Włodarska-Kowalczuk M, Zajączkowski M, Nygård H, Berge J (2011) Seasonal variability of meio-and macrobenthic standing stocks and diversity in an Arctic fjord (Adventfjorden, Spitsbergen). Polar Biol 34:833-845

Pogodina IA (2005) Benthic foraminifera in Hornsund fjord (West Spitsbergen). Oceanology 45:528
Schmiedl G, Mackensen A (1997) Late Quaternary paleoproductivity and deep water circulation in the eastern South Atlantic Ocean: evidence from benthic foraminifera. Palaeogeogr Palaeoclimatol Palaeoecol 130:43-80

Schönfeld J (2012) The FOBIMO (FO-raminiferal Bio-Monitoring) initiative: towards a standardized protocol for soft-bottom benthic foraminiferal monitoring studies. Mar Micropaleontol 94-95:1-13

Schroder-Adams CJ, Cole FE, Medioli FS, Mudie PJ, Scott DB, Dobbin L (1990) Recent Arctic shelf foraminifera; seasonally ice covered vs. perennially ice covered areas. J Foraminifer Res 20:8-36

Skirbekk K, Hald M, Marchitto TM, Junttila J, Klitgaard-Kristensen D, Aagaard-Sørensen S (2016) Benthic foraminiferal growth seasons implied from $\mathrm{Mg} / \mathrm{Ca}$-temperature correlations for three Arctic species. Geochem Geophys Geosyst 17:4684-4704

Syvitski JPM, Asprey KW, Clattenburg D, Hodge GD (1985) The prodelta environment of a fjord: suspended particle dynamics. Sedimentology 32:83-107

Syvitski JPM, Skei JM (1983) Sedimentology of fjords. Sed Geol 36:III-IV

Syvitski JP, Burrell DC, Skei JM (1987) Subaqueous slope failure. In: Fjords. Springer, New York, pp.1-209

Szymańska N, Pawłowska J, Kucharska M, Kujawa A, Łącka M, Zajączkowski M (2017) Impact of shelf-transformed waters (STW) on foraminiferal assembalges in the outwash and glacial fjords of Adventfjorden and Hornsund, Svalbard. Oceanologia 59:525-540

Tverberg V, Nøst OA, Lydersen C, Kovacs KM (2014) Winter sea ice melting in the Atlantic Water subduction area, Svalbard Norway. J Geophys Res 119:5945-5967

Udden JA (1914) Mechanical composition of clastic sediments. Geol Soc Am Bull 25:655-744

Wentworth CK (1922) A scale of grade and class terms for clastic sediments. J Geol 30:377-392

Węsławski JM (ed.) (2011) Adventfjorden. Arctic sea in the backyard. Institute of Oceanology Polish Academy of Sciences, Sopot, Poland, ISBN 978-83-921-552-6-3

Węsławski JM, Szymelfenig M, Zajączkowski M, Keck A (1999) Influence of salinity and suspended matter on the benthos of an Arctic tidal flat. ICES J Mar Sci 56(Suppl):194-202

Wiktor J (1999) Early spring microplankton development under fast ice covered fjords of Svalbard, Arctic. Oceanologia 41:51-72

Włodarska-Kowalczuk M, Szymelfenig M, Zajączkowski M (2007) Dynamic sedimentary environments of an Arctic glacier-fed river estuary (Adventfjorden, Svalbard) II: meio-and macrobenthic fauna. Estuar Coast Shelf Sci 74:274-284

Zajączkowski M (2002) On the use of sediment traps in sedimentation measurements in glaciated fjords. Pol Polar Res 23:161-174

Zajączkowski M (2008) Sediment supply and fluxes in glacial and outwash fjords: Kongsfjorden and Adventfjorden, Svalbard. Polish Polar Res 29:59-72

Zajączkowski M, Włodarska-Kowalczuk M (2007) Dynamic sedimentary environments of an Arctic glacier-fed river estuary (Adventfjorden, Svalbard) I. Flux, deposition, and sediment dynamics. Estuarine Coastal Shelf Sci 74:285-296

Zajączkowski M, Szczucinski W, Bojanowski R (2004) Recent changes in sediment accumulation rates in Adventfjorden, Svalbard. Oceanologia 46:217-231

Zajączkowski M, Nygård H, Hegseth EN, Berge J (2010a) Vertical flux of particulate matter in an Arctic fjord: the case of lack of the sea-ice cover in Adventfjorden 2006-2007. Polar Biol 33:223-239

Zajączkowski M, Szczuciński W, Plessen B, Jernas P (2010b) Benthic foraminifera in Hornsund, Svalbard: implications for paleoenvironmental reconstructions. Polish Polar Res 31:349-375

Publisher's Note Springer Nature remains neutral with regard to jurisdictional claims in published maps and institutional affiliations. 